\title{
The Relation of Secondary Schools to Higher Schools in the United States
}

\section{William Barnard Mooney}

To cite this article: William Barnard Mooney (1916) The Relation of Secondary Schools to Higher Schools in the United States, The Pedagogical Seminary, 23:3, 387-416, DOI: 10.1080/08919402.1916.10534456

To link to this article: http://dx.doi.org/10.1080/08919402.1916.10534456

册 Published online: 30 Aug 2012.

Submit your article to this journal $₫$

Џll Article views: 3 


\title{
THE RELATION OF SECONDARY SCHOOLS TO HIGHER SCHOOLS IN THE UNITED STATES
}

\author{
By William Barnard Mooney, School Visitor and Professor of School \\ Administration, The State Teachers College, Greeley, Colorado
}

It is generally known that the secondary schools of America were founded to train a governing class-ministers and magistrates. For more than a century the subject matter peculiar to the needs of these persons occupied the attention of secondary schools. Keeping in mind the place of Benjamin Franklin in the world of thought, it does not surprise us that he was the first to question the wisdom of this course for America and to give expression to his doubts in an organized effort to bring about a change. This he did in founding the Philadelphia Academy in 1749. According to Franklin's plan this school was to be a school where the boy or girl in the ordinary walks of life might get the rudiments of English, arithmetic, and the casting of accounts. His efforts were not successful, for Franklin was opposed by those whom he was pleased to call the "Latinists." After this abortive effort the "Latinists" remained in more or less disturbed control of the situation until in 1821, when the Boston English Classical School was founded to meet much the same need as that felt by Franklin and his followers more than a half century before. From that date on the struggle to keep the American high school within the beaten paths of the past on the one hand, and to expand it and make it serve the purposes of the ordinary man on the other, has been, and now is, perhaps the most significant educational question before the American people.

In this struggle the educational conservatists have always had, and still have, for the most part, a very great advantage over the progressives, because they are in control of practically all the colleges of the country, and the American people have an abiding, wholesome respect for the edict of their colleges. The colleges themselves have a respect for each other that sometimes borders on fear-fear that their fellow colleges will consider them below standard. To fall below standard, though it be medieval, is the unpardonable sin among American colleges. This fear they have passed on to the American high school, and the high school has passed 
it on to the people. Any one who doubts this should go into any American high school community and ask the first citizen he meets what kind of high school the community has. He will, of course, answer in vague terms, but pin him down to give his very best reason for believing the school to be a good one, and he will finally assert that he must be right because his high school is on the approved list of college so and so, or is on the accredited list of some association of colleges and secondary schools. This is sufficient for most people. They never ask about the basis of accreditation. A threat to remove the high school from the accredited list is sufficient to start a riot among the people of any community; but, ask any one of them why he is so excited about the matter, and he will either frankly fell you that he does not know what accreditation of his high school means, or he may try to convince you that his community is about to suffer a disgrace to avoid which he will go to any length even to advocating those courses exclusively in the high school for which his son or daughter has no need or ability. Better eliminate the boy or girl from the school than to suffer this awful disgrace of being branded as below standard! This is what is happening all over the country. Boys and girls are being sacrificed to a foolish fear which needs to be so thoroughly exposed that it will be obliged to disappear as have the fears of excommunication so powerfully used by the medieval church.

Our peculiar educational system which superimposes one of its parts upon the other has lent itself to the strengthening of the position of the conservatives. Ask any ordinary man again what the purpose of the kindergarten is and he will tell you that it is to prepare for the first grade; what the purpose of the eighth grade is, and he will tell you that it is to prepare for high school; what the purpose of the high school and he will tell you to prepare for college. It is difficult for him to conceive the matter in any other way. And indeed it is not strange, for the whole thing works out that way. The grade below is, in the minds of our teachers, our school boards, our superintendents, in a large percentage of the cases, a preparation for the grade above. This is a false and foolish notion. Once we can conceive the purpose of each grade or each group of grades as the realization of the fullest possible development of the children in the grade or group of grades, not for participation in a future life, but for full and complete participation in the activities of the NOW, we shall have gone a long way toward introducing more happiness and greater efficiency into our public school system.

In their early history the American colleges had their own preparatory schools or depended on private tutoring to fur- 
nish them their students. They then formed the habit of specifying in detail what their students should study to fit them properly for the college. This habit the colleges still have in a large percentage of the cases, some of them devoting a large part of their annual catalogues to these details.

The increased demand for a college education, which came immediately after the civil war, gave rise to the rapid increase in the number of colleges, secular and Christian, especially in the West. This centered the thought of the college authorities upon the problem of preparatory or fitting schools. At first these new colleges looked to the established sources which had supplied the older colleges with students; but it soon became apparent that these were not sufficient, and ways and means whereby the rapidly developing high school might be made a feeder to the college were sought. The University of Michigan has the credit, or discredit, depending upon one's point of view, of proposing, in 1871, the plan which has been so widely adopted by the colleges and universities in the United States. This plan involved the inspection and approval of the secondary school by the colleges and universities, thus placing the secondary school's affairs in complete control of the inspecting schools. So long as the high schools could confine their efforts to fitting for college the plan worked without a great deal of friction, but, as community interests grew, developed, and expanded to a point where a course of preliminary training in the high school would be advantageous to the boy or girl who did not intend to go to college, friction between college entrance requirements and community needs was inevitable. Then arose the slogan of the colleges that that which prepares for college also prepares for life, which was soon neatly turned by the liberals into the more psychological and pedagogical slogan that that which prepares for life also prepares for college. That the effect of the formal discipline idea of the college has by no means disappeared will be noted in the following statement of Professor Thomas $\mathrm{H}$. Briggs:

"Improvement in secondary schools is hampered for several reasons. In the first place, a majority of principals and teachers do not possess a philosophy of education which is satisfactorily based on the newer principles of psychology and sociology. A persistent belief on the part of many that because a subject or a part of a subject is difficult or distasteful, it is therefore educative, that habits acquired in one field are surely transferred to all others, and that native individual differences can be ignored or destroyed, makes progress all but impossible."1

The two clubs which the colleges of the United States have been able to hold over the high schools since $187 \mathrm{I}$ are the

${ }^{1}$ Report of the Commissioner of Education, Vol. I, p. I28. 
entrance requirements and the accredited, or approved, list. Both of these merge, when in action, into one powerful club, which, when wielded by skillful hands, that are by no means lacking, does its work with neatness and dispatch. As has been pointed out, the communities are rare, but fortunately individuals are less rare, that can and do defy the club and its wielders. This system made it necessary for that keen educational observer, President G. Stanley Hall, to say with evident regret :

"One great interest of most high school faculties is fitting for higher institutions-this was of old the prime purpose-although a steadily diminishing proportion of their pupils ever attain that goal. . . The high school has profited almost nothing by the new methods of promotion, which are so beneficent in the grades, by which a bright pupil can shorten his course, and, worst of all, some of the recent concerted prescriptions of the college practically require a full highschool quadrennium, as if the amount of work could be measured by the number of years devoted to it. . . . With a better social position than the teachers of the lower grades, protected and sheltered by the college which has done so much to shape it to its own will, and of which it is often the pampered pet, its representatives usually feel immune from all criticisms of the school system as a whole, and are more secure in their positions. . The college will not and cannot criticise the high school if only it does its own bidding and fits aright, indeed is resentful if others attempt to do so, and few are competent." 2

Educational leaders, who have given this matter consideration, are almost of one mind in urging the emancipation of our high schools from the undue influence which the college is exerting upon them under the scheme of entrance requirements plus the accrediting scheme inaugurated by the University of Michigan almost a half-century ago.

One should not assume or even suggest, perhaps, that this plan has been an absolute evil. What an independent development of the high school might have given us no man can say. That we do have a pretty efficient secondary educational system must be admitted, but that it is as efficient as it can be made, or that it has been as efficient as it might have been, had it remained free to develop its own destinies, is another question that must remain in the realm of opinion. But to point to the past or present greatness of the system, as a justification for its undisturbed continuance, is to apply the well-worn brake on progress, "Let well enough alone," and refuse to study the situation in the light of available facts.

\section{College Entrance Requirements}

The struggle between the conservatives and liberals in the American educational world is well exhibited in a study of

2 F.ducational Problems, Vol. 2, p. 637. 
college entrance requirements. Such a study reveals the fact that among the colleges there are two very distinct groupsthe extremely conservative and the extremely liberal-and that there is a third group not so well defined, leaning on the one hand toward conservatism and on the other hand toward liberalism. The extremely conservative colleges designate all the work which a student must take to prepare himself for college, and the extremely liberal group specifies none of this work, while the group lying between these two extremes prescribes a median amount of the work for college entrance. To get the matter before us in a somewhat more definite way the following table has been prepared:

TARLE I. Showing the number of elective units that are allowed by 317 American colleges, to students entering the liberal arts courses. (All Teachers Colleges and Normal Schools have been excluded from this list but a few Mechanics Arts Colleges and Technical Schools have been included; in such cases the entrance requirements for the engineering or science degrees have been given.)

\begin{tabular}{|c|c|c|c|c|}
\hline $\begin{array}{r}\text { Elect } \\
\text { al }\end{array}$ & $\begin{array}{l}\text { ive units } \\
\text { lowed }\end{array}$ & $\begin{array}{l}\text { No. of colleges } \\
\text { allowing the } \\
\text { units }\end{array}$ & $\begin{array}{c}\text { Perce } \\
\text { the } \\
\text { nu }\end{array}$ & $\begin{array}{l}\text { ige of } \\
\text { gole } \\
\text { er }\end{array}$ \\
\hline & .............. & 16 & & 4.2 \\
\hline $3 / 2$ to & $\ldots \ldots \ldots \ldots \ldots$ & 13 & .................. & 4. I \\
\hline $11 / 2$ to & $2 \ldots \ldots \ldots \ldots \ldots \ldots$ & 23 & ........... & 7.6 \\
\hline & $3 \ldots \ldots \ldots \ldots \ldots \ldots$ & $3 \mathbf{I}$ & $\ldots \ldots \ldots \ldots \ldots \ldots$ & 9.9 \\
\hline $31 / 2$ to & $4 \ldots \ldots \ldots \ldots \ldots \ldots$ & 60 & $\ldots \ldots \ldots \ldots \ldots \ldots$ & 19.2 \\
\hline to & $5 \ldots \ldots \ldots \ldots \ldots \ldots \ldots$ & 52 & $\ldots \ldots \ldots \ldots, \ldots$, & 16.5 \\
\hline $51 / 2$ to & $6, \ldots \ldots \ldots \ldots \ldots \ldots$ & 61 & $\ldots \ldots, \ldots \ldots \ldots, \ldots$ & 19.4 \\
\hline & $7 \ldots \ldots \ldots \ldots \ldots \ldots$ & 23 & $\ldots \ldots \ldots \ldots \ldots \ldots$, & 7.6 \\
\hline to & $8 . \ldots \ldots \ldots \ldots \ldots \ldots$ & I5 & $\ldots \ldots \ldots \ldots \ldots \ldots \ldots$ & 4.7 \\
\hline & $\ldots$ & II & $\cdots$ & 3. \\
\hline $9 \% / 2$ to & 10.. & 6 & & 1.9 \\
\hline $01 / 2$ to & $13 \ldots$ & 3 & n.m.n. & .9 \\
\hline & 15. & 3 & $\cdots$ & .9 \\
\hline
\end{tabular}

From this it will be noted that only 16 or $4.2 \%$ of these 317 colleges are extremely conservative and that only 3 or $.9 \%$ are extremely liberal; and that those that incline most closely to these extremes are likewise limited in about the same proportion. It is interesting to note that 173 or $55 \%$ allow from three and one-half to six limited elective units. The explanation of this lies, no doubt, in the influence exerted by tradition, reinforced by imitation and the recommendations of various organizations that have investigated and reported on the matter of college entrance requirements.

If one should make an arbitrary division of these $3^{17} \mathrm{col}-$ leges, calling those that allow six, or less than six, units of limited electives conservative or inclined to be conservative, and those that allow six and one-half or more than six and 
one-half units of limited electives in the preparatory work, liberal or inclined to be so, some interesting facts are revealed. Such a division places 253 or about $80 \%$ of them in the conservative or inclined to be conservative class, and $6 \mathrm{I}$ or about $20 \%$ in the liberal or inclined to be liberal class.

The following table will give an idea of the geographical distribution of these two classes, which are made, it must be kept in mind, on an entirely arbitrary basis.

TABLE II, showing geographical distribution of colleges designated as conservative and inclined to be conservative, or liberal and inclined to be liberal.

$$
\begin{array}{cc}
\text { No. of conservative } & \text { No. of liberal colleges } \\
\text { colleges or college } & \text { or college allowing 6 } \\
\text { allowing } 6 \text { or less } & \text { or more limited elec- } \\
\text { limited electives } & \text { tives in prep. work. }
\end{array}
$$

State

Alabama. . . .......... in prep. work.

Total

Arizona. . . . . . . . . .

Arkansas. . . ........

California. . . ..........

Colorado. .........

Connecticut.

District of Columbia

Florida.

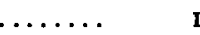

$\ldots \ldots \quad 4$

$\ldots \ldots 2$

$\ldots \ldots .6$

$\ldots \ldots \ldots$

n.....

$\ldots \ldots \ldots 5$

........

$\ldots \ldots . .3$

$\ldots \ldots \ldots$ I

...... 3

$\ldots \ldots \ldots$ o

$\ldots \ldots$

Idaho. . . .........

Illinois.

.......

Indiana. . . ..........

$\ldots \ldots$

Iowa.

$\ldots \ldots \ldots$

Kansas.

........

$\ldots \ldots$

Kentucky.

........

Maine. . . ..........

$\ldots \ldots$

Maryland. . . ......

........

$\ldots \ldots \ldots$

...... 4

....... 6

$\ldots \ldots$ I

$\ldots \ldots \ldots \quad 23$

$\ldots \ldots \ldots$ 12

$\ldots \ldots$. I6

.......

...... 8

$\ldots \ldots \ldots \quad 3$

...... 3

$\ldots \ldots \ldots 5$

$\ldots \ldots \ldots$ 10

Michigan. . . .....

Missouri. . . .........

Minnesota. . . .......

Nebraska. . . ......

New Hampshire ....

New Jersey ........

New Mexico ........

New York .........

North Carolina .....

North Dakota ......

Ohio.............

Oklahoma. . . .......

Oregon.

........

(n....

$\ldots \ldots \ldots$ 3

$\cdots \cdots \cdots \cdot 2^{2}$

....... 3

$\ldots \ldots \ldots$

$\ldots \ldots \ldots 7$

…. 7

....... 2

....... I

.......

....... o

$\ldots \ldots \ldots \quad 3$

$\ldots \ldots \ldots$ I

$\ldots \ldots \ldots$

$\ldots \ldots \ldots$ 22

.......

$\ldots \ldots$ I

...... 3

...... 29

$\ldots \ldots \ldots$ 2

....... 2

....... 5

....... 20

ennsylvania. . . ....

Rhode Island ........

South Carolina .......

South Dakota ........

Tennessee. . . ......

Texas.

..........

$\ldots \ldots \ldots$

$\ldots \ldots$

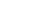

0.0 .0

2

$\ldots \ldots \ldots$

......

$\ldots \ldots \ldots$

$\ldots \ldots$ 
Utah. . . ...........

Vermont. . . ..........

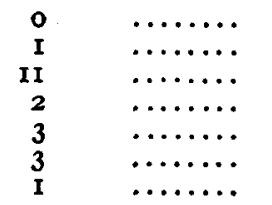

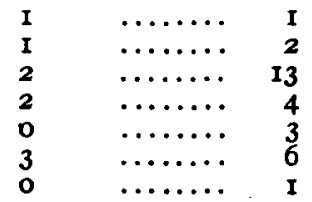

It seems to be generally assumed that the colleges of the West are much more liberal in their entrance requirements than the colleges of the East. From the above table such does not appear to be the condition in so pronounced a way as has been assumed. Of the $I 7$ states in which there are no liberal colleges, on the assumed basis of classification, nine of them are east and eight west of the Mississippi. One is somewhat surprised that in such states as Kansas, Nebraska, Oklahoma and Colorado there are no colleges that will allow the student to elect, in even limited fashion, as many as six and one-half units of his college preparatory work.

Among the 6I liberal colleges we find, however, the following great schools of the West:

Leland Stanford Jr. Univ. allows practically free election.

University of Chicago allows limited election of 12 units.

University of Iowa

Northwestern University

University of Wisconsin

University of Illinois

University of Missouri

University of No. Dakota

University of So. Dakota

University of Michigan

$\begin{array}{lllll}\text { " } & \text { " } & \text { " } & 61 / 2 & \text { " } \\ \text { " } & \text { " } & \text { " } & 7 & \text { " } \\ \text { " } & \text { " } & \text { " } & 9 & \text { " } \\ \text { " } & \text { " } & \text { " } & 9 & \text { " } \\ \text { " } & \text { " } & \text { " } & 9 & \text { " }\end{array}$

East we have the following schools that are included in the liberal class:

Clark College of Clark University allows practically free election.

Pennsylvania College allows limited election of $91 / 2$ units.

University of Pittsburgh

University of Vermont

University of Florida

Ohio State University

DePauw University

Tulane University

"

"4

$\begin{array}{lll}\text { " } & 9 & 4 \\ \text { " } & 9 & 4 \\ \text { " } & 7 & 4 \\ \text { " } 6 \mathrm{I} / 2 & \text { " } \\ \text { " } 7 & \text { " }\end{array}$

This is a clear indication that the spirit of more freedom for the high schools is not confined to the West. While these Eastern schools are not relatively so large as those given for the Western states, they have in them a vitality that has been

* Since the above was written the University of Missouri has further liberalized her entrance requirements. It now admits students on somewhat the same plan as Leland Stanford Jr. University. 


\section{RELATION OF SECONDARY TO HIGHER SCHOOLS}

felt and is being felt in the educational policies of eastern educational institutions.

The following table has been prepared to show the number of colleges that will allow from $1 / 2$ to 15 elective units in the preparatory work, and the number and percentage in each group which will recognize some vocational work as fulfilling entrance requirements. The amount of such work that will be accredited varies from $1 / 2$ to 5 units.

TABLE III

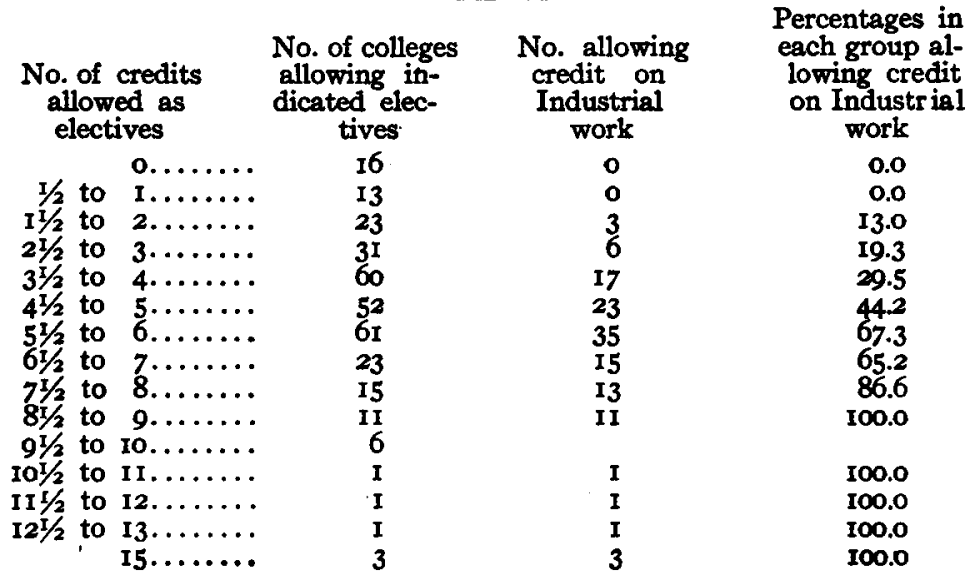

From the above table it will be noted that as colleges become more liberal in the number of elective units, they also become more liberal in the scope of the subject matter from which such electives may be chosen. A glance at the table shows us that 45 , or about three-fourths of those colleges that we have heretofore termed liberal-those allowing six and one-half or more elective units in the preparatory workrecognize industrial training as legitimate college preparatory material. It is also significant to note that of those colleges we have heretofore classified as conservative, only 84 or about one-third recognize such work as permissible entrance material. From the table it further appears that after a college has reached a point where it is willing to let the high school pupil choose, from a limited field, as many as $8 \mathrm{t} / 2$ units of his preparatory work it also is willing that at least some of this shall be in vocational work. The number so recognized by these schools varies from one to five units, but most of them will recognize four or five of such units. This tendency is what gives alarm to the educational conservatives. 
To maintain the foregoing standards, colleges, as a rule, have adopted an inspection and accrediting system. In this work they are powerfully supported and assisted by what we shall call

The Voluntary Educational Associations of America

There are four of these associations in the United States that are directly active in this work and several other organizations that cooperate with them. The active ones are:

I. The New England Association of Colleges, with its active committees, The Examining Commission and College Entrance Certificate Board.

2. The Association of Colleges and Preparatory Schools of the Middle States and Maryland, with its active body, the College Entrance Certificate Board, which, since its creation, has become an independent organization.

3. The Association of Colleges and Preparatory Schools of the Southern States, with its active bodies, the Accrediting Commission and Examining Committee.

4. The North Central Association of Colleges and Secondary Schools with its active bodies, the Accrediting Commission and Board of Inspectors.

In addition to these there is the National Association of State Universities, and finally, an association of all these associations known as The National Conference Committee of Colleges and Secondary Schools.

The New England Certificate Board bases its system of accrediting of high schools on the success of students who attend the colleges that are members of the board. The strict enforcement of these rules, most of which are very arbitrary and some, we think, unjust, has made the Certificate Board the mark of some very vigorous attacks recently. These attacks have resulted in the withdrawal of Dartmouth and the University of Maine from membership in the board, and in a somewhat general opinion that the board will need to change its methods or go out of existence.

The Association of the Middle States and Maryland thus far seems content to allow the College Entrance Certificate Board, of which it is the mother, to determine, through its system of examinations, the standards for the association.

The North Central Association of Colleges and Secondary Schools and the Association of Colleges and Preparatory Schools of the Southern States have practically the same standards and methods of operation; hence a brief description of the standards and system of accrediting high schools followed by the North Central Association will serve in the 
main for both organizations. The standards for high schools belonging to the North Central Association are as follows:

I. That the minimum scholastic attainment of all teachers in a high school shall be the equivalent of graduation from a college belonging to the North Central Association including special training in the subject they teach, such requirements not to be retroactive.

2. Daily periods for any teacher not to exceed five. No school will be considered whose teachers teach more than six periods per day.

3. Laboratory and library facilities must be adequate for efficient instruction.

4. Inspectors shall take account in addition to the above the esprit de corps, the efficiency of instruction, acquired habits of thought and study, intellectual and ethical tone of the school. To be favorably considered a school must rank high in all of these.

5. Standard ratio of teachers to pupils is I to 25 .

6. Schools on the borderline of points are not recommended for accreditation.

7. Schools of less than 5 teachers are not eligible.

(I) The organ of communication between the commission and the secondary schools is as follows:

First, the inspector of schools of the state university where such exists.

Second, the inspector of the state department or

Third, where neither of these exist then some one may be designated by the secretary of the accrediting committee.

(2) The report is first made to the state authority and by him transmitted to the Secretary of the Commission.

(3) The Commission on Accreditation has power to specify, by way of recommendation, the outlines of work which should be followed in the high schools. Considerable work has been done along these lines, units having been prepared in English, mathematics, history, Latin, Greek, German, French, Spanish, Physics, Botany, Commercial subjects, and manual training.

(4) The Board of Inspectors consists of the inspectors in each state. They meet annually and make recommendations to the accrediting committee, and this committee in turn makes its recommendations to the North Central Association where final action is taken. In I9ro the Board of Inspectors reported a great increase in the demand for industrial work in the high schools, and expressed alarm at the tendency of high schools to ignore, in the selection of their teachers of these subjects, the qualification standards approved by the 
association. They urged that the colleges belonging to the association establish at once teachers courses in music, art, manual training, domestic science, etc. The report was approved, and now the association favors introducing the so-called industrial subjects, where local conditions render such introduction feasible; but the inspector will hold that a sufficient number of qualified teachers must be added to provide adequately for such instruction.

Warnings are sent out by both the North Central and Southern associations to schools that have fallen below standard. These warnings, in the case of the North Central Association, are sent out by the Board of Inspectors which consists of the inspectors of the entire territory. These warnings are based upon the report of the inspector from each state, but the fact that they are sent out by the entire Board of Inspectors makes them far more powerful and significant to school officers and communities. Under this plan few communities or school men can afford to ignore the mandates of the inspector of the association. If one could convince himself that the inspector for his state is all-wise in educational matters and that the path marked out by the association standards is the path all those seeking an education must travel, then he could throw his hat in the air' and "go down the line" for the plan, for it is one admirably devised to take the educational affairs of the people from them and place these affairs in the hands of educational experts, who solemnly sit in judgment on a school a thousand miles away, which they have never seen and about whose intricate problems of administration they can know little if anything. But when he is in doubt about the "expertness" of the experts, and when he fears that the path marked out by the association is not the path which all can or must follow if they would become educated, then indeed is he perplexed. To express such a fear may lead to educational ostracism, but an increasing number of men are taking these chances today, because they see in these associations a tendency to centralize our educational affairs and place them in the hands of a selfappointed authority, over which neither state nor nation can exercise any control.

The map on page 398 will indicate the territory in which each of these voluntary educational associations is active.

A study of the origin and activities of these voluntary education associations reveals some interesting facts. It seems that:

I. They have been originated at the instance of men in secondary and college educational work. The former have 


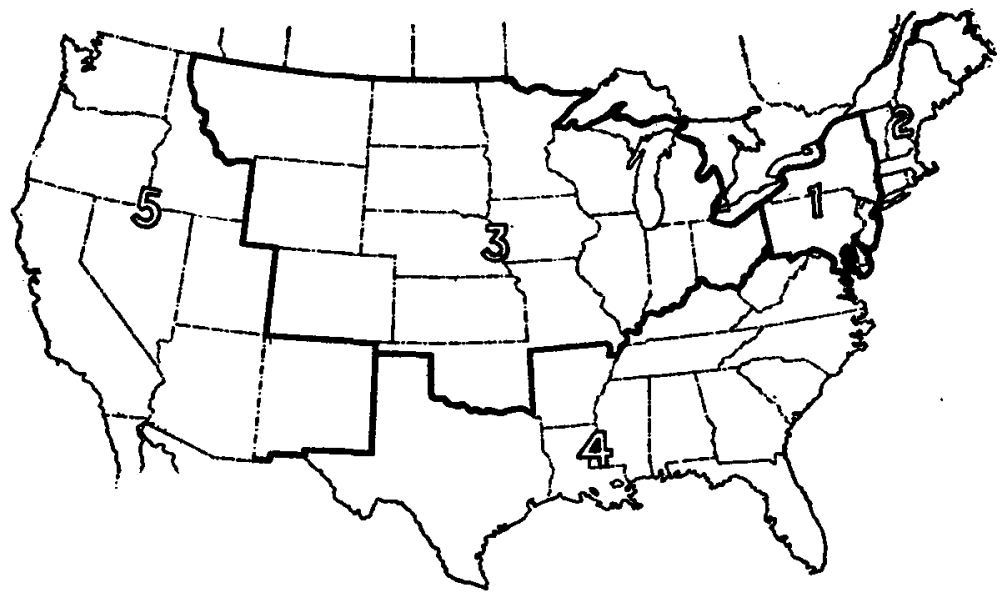

1. Territory of the Association of Colleges and Preparatory Schools of the Middle States and Maryland. 5 States.

2. Territory of the New England College Certificate Board. 6 States.

3. Territory covered by the North Central Amociation of Colteges and Secondary Schools. 16 States.

4. Territory covered by the Association of Colleges and Preparatory Schools of the Southern States. 13 States.

5. Unorganized Territory.

been even more active in the initial steps of organization than the latter.

2. Whatever their original purposes may have been they very quickly assumed more or less positive direction of secondary education in the territory comprehended in each.

3. This control and direction first took the form of college entrance examining boards, commissions or committees. The work of these committees was soon supplemented by the creation of accrediting committees or commissions with their elaborate systems of inspection and approval.

4. There is a marked similarity in their standards of accreditation. So true is this that one may say with conșiderable assurance that their educational standards, on paper at least, are the same.

That these organizations have served and are serving a good purpose in education cannot be doubted by any one familiar with the facts. The large question is, however, whether the good they do will compensate for their evil deeds and tendencies?

They tend to increase educational equipment and academic training of teachers in our high schools, but do they do this at the expense of local initiative and at the expense of real professional standards? 
They tend to hold the attention of high school teachers to the traditional high school subjects, but do they do this at the expense of community and life subjects?

Their tendency is undoubtedly toward a national standardization of secondary education as well as college and university education. Is this desirable? Is it contrary to our notions of government?

Have we already begun to revolt? Does not the action of some of our states and institutions to which reference will be made later, together with a very general feeling that we have too much supervision from the top, indicate such a spirit among us?

These associations make detailed outlines of courses to be pursued in the high schools; thus they relieve the high school principal and his teachers from much of the necessity of considering the method and material of instruction in these schools: but in doing this have they taken from these teachers duties and responsibilities necessary to their own growth and development in their chosen profession?

They center the thought of the secondary and college teachers upon the subject matter of instruction, but do they thereby crowd out the disposition to study the needs of boys and girls in their relationship to this subject matter?

They tend to compel the high schools to x egard themselves and to be regarded as preparatory schools, and thus lay these schools open to the charge of being the "pampered pets" of the colleges for which they "fit." Can an institution so regard itself or be regarded and reach the greatest development of which it is capable?

Concerning some of the other items the writer has not come to any definite conclusions, but upon this last point he has the very positive conviction that no school can reach its greatest possibilities to serve the people who attend it or who support it when it regards itself as a preparatory school for a higher one. This is true of the kindergarten, the elementary school, the high school or the college.

The Effect of the Work of the Voluntary Educational Association and of College Entrance ReQuirements on the High Schools of the United States

Believing that the men and women working under or directly observing a system in action can best judge of its merits or demerits, we have made an effort to find out from them what the effect of college entrance requirements and the activities of the voluntary education associations has been on educational practices and efforts as they have observed it. 
To this end the following questions were sent, with proper modifications in the third question, to practically all the high school principals whose schools are on the accredited lists of The North Central Association of Colleges and Secondary Schools and of The New England Certificate Board:

I. What changes, if any, would you make in your course of study if the colleges accepted your graduates, who presented the required number of units, without specifying the subjects in which these units are to be earned?

2. A few colleges and a number of normal schools and Teachers Colleges are accepting graduates of high schools on the basis indicated in No. I above. Would you favor such an attitude on the part of all colleges?

3. In what ways have the college entrance requirements of the colleges of your state or the work of the North Central Association affected your high school?

Space will not permit a full report of the answers received to these questions, but a classification and summary of the answers may prove interesting:

402 or about $32 \%$ of the letters sent out were answered. Practically the same ratio of answers to letters sent out came from each territory.

An analysis and tabulation of the answers to the first question show that

I. 23 I or about $60 \%$ would make changes in their courses of study under the conditions named in question ( $I$ ).

2. 156 or about $40 \%$ would make no changes.

3. 48 or $12 \%$ would make changes in science, most of which would tend to make the subject less formal or elective.

4. 57 or $14 \%$ would make changes in mathematics, most of which would be to make the subject elective.

5. I6 or $4 \%$ would make minor changes in history.

6. 28 or $7 \%$ mention changes in English, most of which would tend to make this subject less formal and more practical.

7. 59 or $15 \%$ would make changes in foreign language requirements, most of which would be to make such courses elective.

8. 74 or $18 \%$ would increase their industrial work. Most of these would introduce or expand courses in domestic science, manual training, agriculture, stenography and typewriting.

9. 75 or $18 \%$ do not mention any particular subjects, but speak of general adjustments, most of which would tend to adapt the courses to the needs of pupils.

There is evidence that East and West there is a desire among high school principals for greater freedom to make 
adjustments in their high school courses, so that they might more effectively meet the needs of individuals and communities; and further, there is evidence that entrance requirements interfere materially with such efforts. On the other hand there is not much evidence in the foregoing to support the idea that such freedom would result in chaos in the high school courses of study.

To summarize the answers to the second question:

II or about $3 \%$ did not answer the question.

148 or about $37 \%$ answer the question "No."

243 or about $60 \%$ answer it "Yes."

Comparing the same items in the two territories:

I. The Certificate Board Territory

4 or about $3 \%$ did not answer the question.

57 or about $40 \%$ answered the question "No."

$8 \mathrm{I}$ or about $57 \%$ answered the question "Yes."

\section{The North Central Territory}

7 or about $3 \%$ did not answer the question.

91 or about $36 \%$ answered it "No."

162 or about $61 \%$ answered it "Yes."

There is a striking similarity of opinion on this question among high school principals, east and west, if one may take the above as a criterion. It would seem that almost twothirds of the principals in the North Central territory believe in complete freedom for their schools, and that only a slightly smaller percentage of the New England principals agree with them. That there is a strong minority who hold an opposite view cannot, however, be ignored.

Summarizing the answers to the third or last question:

\section{From the Certificate Board's Territory}

I. I3 or about 10\% of those answering from this territory do not answer this question.

2. 22 or about $15 \%$ say the influence of the Board has been negligible.

3. 50 or about $35 \%$ say the influence of the Board on their schools has been good.

4. 57 or about $40 \%$ say the influence has been bad.

From the North Central Territory

I. 8 or about $3 \%$ of those answering from this territory do not answer the question. 
2. 52 or about $20 \%$ think the influence on their schools has been negligible.

3. I28 or about $49 \%$ are inclined to approve the work of. the Association and the influence of entrance requirements.

$4 \times 72$ or about $28 \%$ are adversely critical.

A summary of the combined results of the answers to the third question show:

21 or about $5 \%$ not answering the question.

74 or about $18 \%$ saying the influence has been negligible.

I 78 or about $44 \%$ approving the association and entrance requirements.

I 29 or about $33 \%$ adversely critizing both.

We regret that space will not permit us to quote the many opinions expressed on the issues raised by these questions. We cannot refrain, however, from quoting one opinion, which though unique in expression, is typical of a very large number of opinions of high school principals, East and West, who expressed themselves on the third question which, it will be recalled, related to the effect that college entrance requirements have upon the high schools.

"Deadened, formalized, mummified, our work in embalming everything into ' units.' Witness the ghastly 'pedagogization' of manual training the country over." Principal F. L. Sims, South Bend, Ind.; 54 teachers in the high school.

The Logan County High School at Sterling, Colorado, was recently refused admission to the accredited list of the North Central Association. The reason for this is given in the following quotation from a letter received from the present principal, J. A. Sexson.

"In the case of our high school the North Central Association attempted to dictate to the School Committee the subject matter to be embodied in the curriculum. As a basis for this dictation they seemed to be guided by the traditional college standards and they refused steadfastly to permit the consideration of teachers or subject matter that in any respect failed to meet certain standards preconceived as necessary. They went so far as... to threaten to penalize the school committee should they employ a principal who was personally distasteful to the examiner. They especially opposed the introduction of such subjects as blacksmithing, agriculture, household arts. . . In other words, they opposed any attempts to widen the field of service of the school even though this was to be done at no special detriment to the traditional subjects."

It should be said that the School Committee of this school refused to listen to the demands of the examiner, elected the principal to whom objection was made, and allowed him to organize the school and make of it a school which any col- 
lege, university, or association would be glad to recognize as first class. Thus far, however, the school has refused to be put on any of their accredited lists, though the principal and school committee have been repeatedly urged to fill out the necessary blanks.

In order to get the view point of others than high school principals on the matter in hand, the foilowing questions were sent to all State Superintendents of Public Instruction and Normal School Presidents in the United States:

I. "If you have observed any of the so-called college or university domination of high schools in your state, in what form does it find expression?" Under this question were others that referred to the matter of employing teachers, method of accrediting high schools, conflicts between entrance requirements and community interests, and to the giving of examinations for determining college entrance.

2. "It is generally believed that it is in the small high school where the college entrance requirements are in most frequent conflict with community subjects. What, in your judgment, should be the solution to the problem presented in these small high schools?"

Fifty-five normal school presidents replied and thirty-six State Superintendents or representatives of these officials. Thirty-eight of the normal school presidents have observed what they consider "domination" of varying degrees; sixteen have made no such observations and one was indefinite in his answer. Nine State Superintendents have observed what they consider "domination"; twenty-three have made no such observations, and four were indefinite in their answers.

In answering the second question, "What, in your judgment, should be the solution to the problem presented in the small high schools?" we have considered that they are really stating whether they think the college should adjust itself to the high school or the high school to the college. The question then might have been, Should the college adjust itself to the high school? Putting it this way we find that of the fifty-five normal school presidents thirty-two answer the question "Yes", none answer it "No"; four say there are no conflicts between community and college entrance subjects in their states; twelve are indefinite and seven do not answer the question. Of the thirty-six State Superintendents or their representatives, fifteen answer it "Yes"; three answer it "No"; seven say there are no conflicts; seven are indefinite; and four do not answer the question or rather state no opinion as to the solution of the problem. 


\section{RELATION OF SECONDARY TO HIGHER SCHOOLS}

The foregoing indicates that workers in the educational field generally admit the efficiency of college entrance requirements, in that they succeed in their purpose, which is to center the attention of high school teachers and pupils upon the subjects regarded by colleges as essential to proper preparation for college work. It is also evident that they generally concede that the voluntary educational associations are efficient, in that they secure for high schools better prepared teachers, at least from the standpoint of academic training; that they increase school equipment and tend to make the educative process uniform through the standardization of both matter and method in our secondary schools. Admitting all this, it is evident that many of our educators are seriously questioning this kind of "efficiency" and are of the opinion that we are purchasing this apparent progress at too great a price, when we must pay for it by closing our eyes to the individual differences in children, by handing over important phases of educational administration to self appointed authorities, whose intentions are of the best, but whose methods insidiously undermine the democratic structure of our educational system. If viewed from an angle that is too narrow, the doctrine of efficiency is a dangerous one in all fields of human endeavor, but it is particularly dangerous in the field of education. The question is, not only how efficient is the school now, but how efficient will it be a thousand years from now? We contend that that educational system, which is an outgrowth from the people, will develop, perhaps more slowly, but it will develop more surely and in the long run will be the most efficient.

\section{Views of College and University Presidents on the Subject}

Beginning in July, rgi5, the New York Times asked a number of college presidents to give their opinions on methods of teaching, courses of study, and topics that had been too much or too little emphasized in the past in the preparatory schools of the United States. Some interesting replies were received.

In the issue for 'July I3, I9I5, President Hall of Clark University expressed himself as follows:

"The thing most needed now is the complete emancipation of high and preparatory schools from college prescription, which in the beginning of it did good but has lately become, in the East, almost an unmitigated curse. The high school should be the people's college and say to the higher institutions: 'Here are our graduates. We have done our best to teach them what their stage of life most needs."

In the issue for July 25 , I9I5, the following college and university presidents expressed opinions: 


\section{President Nicholas Murray Butler, Columbia University:}

"It is best not to use the words preparatory school at all or get into the habit of thinking which the use of that term implies. The secondary school should not be merely a preparatory school but should stand upon its own feet and do the work appropriate to the age of its students and to the environment in which they live."

President Frost of Berea College, Kentucky, says that the problem presented in the small high school is a "burning question today." $\mathrm{He}$ is inclined to think the college should "clear the way for entrance for the boy who has graduated from a small high school and has not had a full list of studies ordinarily required for college preparation."

\section{President Aley of the University of Maine:}

"Institutions of higher learning need to go further than they have in adjusting their work to the preparation that the high schools give. It should be as easy to pass from the high school to the college as it is to pass from the grammar school to the high school."

President Hughes of Miami University, Ohio, thinks we should select those "subjects which are worth while and real and which will function somewhat in the life of the student" and then give these in "a way which will demand thorough preparation and first-class drill" on the part of the pupils of the high school.

Under date of Aug. I, 1915, is the following:

President Blaisdell of Alma College, Michigan:

"Any regular four-year high-school course should be accepted as giving adequate training for college work. The colleges are rapidly coming to this position. The high school should insist on it. Many a lad receives his first impulse after three years in high school. Shall he be compelled to study an additional year or two before he will be admitted to college merely because he has not taken a 'college preparatory course?' Educational nonsense! It is mental training not information, that should admit to college."

President Cole of Wheaton College, Norton, Massachusetts :

"My sympathies are with the plan that will give the preparatory school a larger freedom, if this can be done, as I believe it can without any sacrifice, but with some improvement in the quality of scholarship and in the preparation for college work. The first step must come from the college. The college might further broaden the scope of the preparatory work it will accept, and still leave entrance into college more difficult than entrance into the Holy City, the latter having many avenues of approach, on the east three gates, on the north three gates, on the south three gates, and on the west three gates." 
Under date of August 18, 1915, the following:

President Hill of the University of Missouri:

"As for the content of instruction in secondary schools that should be determined largely, if not wholly, by consideration as to what is best for a pupil of high-school age, regardless of whether he will attend university or not. Youth is the humanistic age and languages, human institutions, practical (not technical) science, and mathematics of a kind that helps to accurate solution of the concrete problems of life should constitute the major part of his study. Not information, not the covering of ground in these studies, should be the aim, but insight, appreciation, subjects studied to the future needs of students. In place of so much mathematics for girls, let the courses substitute an equivalent in home science."

President Pateat of Furman University, Greenville, S. C.:

"In my judgment there is going to be a widespread reaction against the unit system of entrance requirements."

President Brannon of the University of Idaho:

"The preparatory school of to-day must be characterized by courses which provide for vocational training as well as for discipline and culture. I think in too many high schools there is too much emphasis placed upon Latin and other foreign languages."

\section{Under date of Sept. 26, 1915, the following:}

Professor Lange, Director School of Education, University of California:

"If the 'preparatory' school is to advance, it must largely cease to be preparatory and must, instead, become an educational institution conscious of its self-hood as a social organ and functioning, self-directed as the needs of adolescence and of the nation's demands."

This contribution of the Times is stimulating to those who are advocating the emancipation of the high school. It very clearly shows that within the colleges and universities themselves there are differences of opinion as to the amount of freedom which should be given to the high school. From educational literature one is led to believe that the conservative and liberal opinions are held by two distinct groups in the college world. The conservative position is upheld by the Deans of colleges, supported by a group of specialists who have taught themselves to believe, and believe sincerely, that no man can be considered educated who does not possess at least some of the information which they as specialists possess. The liberal opinion, as a rule, is held by the college and university president earnestly supported by the heads of the schools of education. This of course is only an impression gained from current educational literature, but it is believed that a statistical study would verify the assumption. 
Some Movements which Tend to Make the High School AN INDEPENDENT EDUCATIONAL INSTITUTION

In addition to the large amount of educational literature on this subject, most of which is antagonistic to the ideas of those institutions and organizations which would make of the high school a college preparatory school, there have been some recent actions in educational circles which indicate more serious opposition to the purposes of such institutions and organizations.

Dartmouth College recently withdrew its membership in the College Entrance Certificate Board. The reason for this action is given in a letter from Dean Craven Laycock under date of January 4, 1916 :

"I will state as fully as possible the reason why Dartmouth withdrew from the New England (Board.

"Because of the fact that schools in New Hampshire were removed from the list of the Board, thus making it impossible for Dartmouth to accept students therefrom, even though all the students sent to Dartmouth from such schools had been satisfactory. Situated as we are in New Hampshire and feeling a special obligation to the good schools of the state, we felt that we were limited by our membership in the Board in such a way that we could not carry out what seemed to be desirable policies in this regard.

"Dartmouth expressed her desire to remain as a member of the Board, provided freedom could be had in the point above mentioned. Naturally, of course, this could not be granted and the withdrawal from the Board followed."

\section{"(Signed) Craven Laycock."}

This action is significant, especially so when it is recalled that Dartmouth was originally one of the most vigorous advocates of the Certificate Board.

The University of Maine withdrew from the New England Certificate Board in I9I3. When asked for the reasons for the action President Aley wrote under date of November 27, 1915, "The University of Maine withdrew from the New England College Entrance Board because it felt that a state supported institution should not have the entrance of students determined by a Board having no connection with the state."

In his official report for $191_{4}$ Superintendent Payson Smith of Maine, now Commissioner of Education for Massachusetts, after making some general observations on methods of regulating college entrance requirements, says, "Such dissatisfaction as has now arisen in relation to the New England College Entrance Certificate Board is due in part to the following:

I. "It attaches to the school possessing the certificate a fictitious value." 
2. "The undue stress laid by smaller schools on college preparation in order that Board approval may be secured or retained."

3. "The indirect effect on many small schools that cannot consistently apply for or might be eligible for, the privileges accorded by the Board."

4. "The judgment of the school solely on the basis of the result in college."

5. "The colleges of this Board, while indirectly responsible for the effects of its activities on lower schools, are without accountability to the public for those results."

Commissioner Smith discusses each of the above items at some length anci sets forth, what seems to us, some very sound educational principles. Under item three he notes the tendency of young people to go from their local high school to an accredited school of the Board for their last year of high school work. Thus the local school, in which the first three years of the student's work was done, gets no credit for this, but on the contrary it becomes an object of suspicion on the part of the people of the community, as being a school that is not as efficient as the accredited school to which the pupil goes for his final year, merely to avoid the.necessity of taking a college entrance examination. He asserts that Maine cannot afford to thus cripple her small high schools. We believe that if Maine cannot afford to do this, much less can the nation afford to do it. And yet this is the inevitable tendency wherever the standards of these voluntary educational associations are dominant. The North Central Association refuses to accredit a school that has less than five teachers. We are told by Professor Jessup that $60 \%$ of the high schools in the North Central's territory have fewer than one hundred pupils, which would mean, in most cases, less than five teachers; $;^{3}$ and by Dr. E. L. Thorndike that more than $50 \%$ of the high school children of the United States are in high schools of less than five teachers. ${ }^{4}$ These facts are extremely significant to those interested in building up a spirit of loyalty in the rural and village communities.

Under the heading, "What if anything is the University of Wisconsin undertaking that the state as a whole does not wish it to do?" the Survey Committee, headed by Dr. W. H. Allen of the Bureau of Municipal Research, says: "High school inspection for the purpose of accrediting high schools should give way to high school visiting for the purpose of helping the university to keep in touch with state needs

3 School Review 1915. Vol. 23, p. 623.

* Educational Review, 1907, Vol. 33, pp. 245-255. 
. . . ", and further, "That compulsory foreign language requirements (which in effect compel thousands in high schools to take languages for the sake of the few who go to the university), should be discontinued both for entrance and for graduation."

The Board of Public Affairs, in its comments on the above recommendations, when presenting its report to the Wisconsin legislature, says: "High schools have other functions than that of merely preparing graduates for entrance to the university. A majority of those who leave high school go directly into some business or other occupation; only a small minority of high school graduates enter the university or take other college work. Therefore, in the opinion of this board, the curriculum of each high school should be adapted to the needs of the students in its community. The fact that a given subject is of practical value does not divest it of its cultural advantages nor detract from its usefulness as a vehicle for ${ }^{*}$ disciplinary training. There is no necessary antagonism between the two values. University inspection for the sole purpose of improving the quality of instruction in the subjects each community decides to place in its high school is helpful and should be continued." And further, "In the opinion of this board a State university should provide regular courses leading to graduation and degrees without foreign languages of any kind. The value of foreign language training is not questioned. Neither does this board undervalue the opportunity offered for opening to the student rich stores of literature, science, and art. The question is as to whether a state university shall lead through reason and persuasion or through force."

A very significant movement was started in New York city when in I9I0 the High School Teachers Association declared that "The conviction is spreading throughout the United States that our high schools are seriously handicapped by present college entrance requirements."

A committee from this organization formulated two principles or methods of college entrance which would be satisfactory to the Association:

I. "By the first method college entrance would be based upon the simple fact of graduation from a four-year course in a first-class high school. This method would give complete satisfaction to the high school, if supplemented by competent examination into the efficiency of each school, we believe this method would tend to develop within the high school that independence, breadth, and judgment required to

5 Survey of the University of Wisconsin, 1914, pp. 158-9.

- Ibid., pp. 31-2. 
produce the best results. The improvement in the high schools would result in better preparation and more students for the colleges.

The second method calls for:

(a) The reduction in the number of so-called required subjects, together with

(b) The recognition of all standard subjects, as electives."

"The requirement of two foreign languages from every student is regarded as particularly objectionable." $\bar{T}$

Just how much freedom such a plan would give to the high school would of course depend upon the bases of the "examination into the efficiency of each school," and upon the definition of "standard subjects," as well as upon who did the examining and standardizing.

In 1910 the Secondary Department of the National Educational Association adopted the following resolutions:

Whereas, a wide range of high school subjects is now demanded in view of the varied needs of society and the diversified interests of different students, and

Whereas, Manual training, commercial branches, music, household science and art, agriculture, etc., when once taught and thoroughly learned are worthy of, and justly entitled to, recognition in college entrance credits, and whereas colleges in certain parts of the United States continue to require two foreign languages from every applicant regardless of his dominant interests, and

Whercas, this requirement in addition to such work in English, Mathematics, history and science as is essential to the high school course of every student precludes the possibility of giving adequate attention to these other subjects, therefore be it

Resolved, that it is the sense of the Secondary Department of the National Educational Association that the interests of high school students would be advanced by the reduction of the requirement in foreign language to one such language and the recognition as electives of all subjects well taught in the high school, and be it further

Resolved, that it is the sense of this Department that until such modification is made by the colleges, the high schools will be greatly hampered in their attempts to serve the best interests of boys and girls in the public high schools.

Practically the same resolutions were adopted by the Department of Manual Training and Art Education, and the Department of Business Education of the National Education Association at their meetings in July of 1910.

These resolutions were adopted in the secondary department with but one dissenting vote. As a result the committee of nine was appointed with $\mathrm{Mr}$. Clarence $\mathrm{D}$. Kingsley of Boston as chairman. This committee has done excellent work in the cause of greater freedom for our secondary schools.

${ }^{7}$ Articulation of High School and College, High School Teachers Association, New York City, 1910, pp. 4-5. 
At a recent meeting the superintendents in Massachusetts, representing towns from 5,000 to 10,000 population, adopted a resolution vigorously advocating admission to college on the basis of "having completed fifteen units of high school work of the grade heretofore required for college certification." They also advocated a more comprehensive recognition of subject matter which would fulfill entrance requirements.

Inspection of high schools has been the cause of much bitter controversy in the west and middle west. In some states this opposition has expressed itself by a demand that inspection and accreditation of high schools be done by the State Department. The states of Ohio and Kansas have very recently, by act of the legislatures of these states, taken the power of inspection and accreditation out of the hands of their universities and placed it with the state departments.

The arguments for doing this in Kansas are given by State Supt. W. D. Ross in his annual report for 1913. These are representative of the arguments that are being used elsewhere to bring about similar changes:

"As a matter of fact the standardization of high schools for college entrance requirements, for certificating privileges, for state aid and for all other purposes should be under the control of the State Board of Education. And no other agency should be permitted to attempt it."

"The reasons for this are obvious. Such a plan would be more systematic, it would be more uniform, it would be more economical, it would be just and it would be more effective than any system of partial or divided supervision could possibly be."

It is noteworthy that many of the organized movements against too much interference with the affairs of the high school by the higher schools, have occurred within the last five or six years. It has taken the form (I) of protest, (2) of colleges severing relations with voluntary educational accrediting associations, and (3) of legislative action by the states. Of course the last two forms are of the greatest educational significance and are the natural outcome of the protests that have been so long and vigorously expressed in educational meetings, organizations and publications.

\section{Some Possible Methods of Dealing with the Problem}

There are at least four ways, as we see it, of dealing with this question of college entrance. First, to let the higher school continue to prescribe the secondary school courses through the entrance requirements. Second, to put college 
entrance into the hands of a voluntary educational body such as the College Entrance Examination Board. Third, to transfer the power of accreditation to the state departments of education, and require public supported schools to admit students who are graduates of such approved high schools. And fourth, to leave the matter in the hands of the local authorities, the colleges and state departments assuming an advisory attitude toward the high schools.

We have already suggested reasons for not continuing or extending the first method of dealing with the problem, but a summary and perhaps some addition to these reasons may be stated here.

I. Such a plan tends to over-emphasize subject matter and under-emphasize the effect of subject matter on the growing child.

2. Such a plan draws the curtain on the individuality of children. When a student asks his principal or high school teacher what subjects he should pursue in high school the reply is, "What college do you wish to enter?" and upon the answer to this question the student's high school course is based, rather than upon an inquiry into the child's adaptabilities, interests, or life ambitions beyond the college.

3. Such a plan tends to make the high school regard itself and be regarded by its patrons as a school that is subservient and subordinate to the higher school. No school can so regard itself and give the people who support it, or the children who attend it, the best services of which it is capable.

4. Such a plan tends to over-emphasize the future needs of the child and under-emphasize the "now" in his life. It is believed that the child that fully participates in the life and interests of the present is thereby made more capable of entering into the tasks of the future, whatever they may be.

5. Such a plan relieves the high school teacher, principal, and community of tasks of administration, the performance of which, we believe, is essential to a full measure of growth in their profession on the part of these teachers, and to a full measure of growth along the line of self-government on the part of the high school community.

6. Such a plan tends to sacrifice the interests and needs of the many who do not go to college for the supposed interests and needs of the few who do. This is especially true of the smaller high schools.

The second plan has all the objections of the first with the added one, which is best expressed in the already quoted statement from President Aley of the University of Maine: "The University of Maine withdrew from the New England College Entrance Board because it felt that a state supported 
institution should not have the entrance of its students determined by a Board having no connection with the state."

The third plan, that of having state departments of education determine college entrance standards, is strongly advocated by some of the thoughtful educators in the country. That such a plan is or would be a complete solution, we presume, is not believed by all those who advocate it. But that it is much better than either plan one or two, is believed by all educators who think the people who support their schools should have a voice in their management. It may be said, of course, that state supported schools are quite as much under the direction of the people as state departments of education. This is true, theoretically, but practically state schools are, as a rule, less responsive to public demands than state departments of education. And herein lies, as many see it, one of the grave dangers of adopting the third plan, as some states have already done. This danger is that the exigencies of political parties may put into the offices of state superintendents those who do not have a broad conception of their work and by reason of this fact high schools as well as colleges may suffer at their hands. As we see it, this plan may have practically all the objections urged against it as the first plan. The courses that have been outlined for high schools by state departments, for the purposes of accreditation, show that they are quite as narrow as the college prescriptions, and indeed they give one the idea that college entrance standards have guided in the making of these courses. Principal W. D. Lewis makes a significant statement in this connection:

"Any attempt to extend the number of subjects or to change the
scope of existing requirements for college entrance is met with
suspicious scrutiny on the part of many colleges. Even the authority
of the New York State Education Department is powerless to add
or subtract one jot or tittle in the matter of college entrance units.
By its dispensation of public money this department can dictate courses
of study, the qualification of teachers, and the methods and scope of
instruction in the high schools; but the necessity of having its cre-
dentials accepted for entrance has generally forced it meekly to
follow college suggestion. Hence the Regents' examinations, by which
the high school pupils of the state are measured, are really college
entrance examinations in another form."

The same kind of situation may arise where entrance is by certificate rather than by examination. Unless the state department remains free from the narrowing influences of the higher institutions it may become a more powerful agent for the destruction of high school independence than the college could possibly be.

8 Democracy's High School, I914, p. 86-7. 


\section{RELATION OF SECONDARY TO HIGHER SCHOOLS}

One of our correspondents furnishes an example of the miserable red tape which may be drawn around a high school by the rules of a state department that has the power to accredit high schools. Supt. E. L. Rickert of Connersville, Indiana, says: "The only restriction that really hurts us is the requirement in foreign language. We have pupils that ought not to do this. Foreign language and mathematics may be omitted by special permission of the State Board of Education for each pupil."

Such rules as these, while they may not be common, nevertheless are possible, and experience tends to show that they increase rather than decrease under a bureaucratic system into which the third plan of high school control tends to develop. We believe that it should not be adopted with too much assurance that it will solve our problem; and we are inclined to believe that it is better to suffer our present ills than to go over to a system fraught with so many harmful possibilities. In states where commissioners of education are appointed for an indefinite period the dangers may be lessened or they may be heightened, depending of course on the educational viewpoint of the commissioner.

The fourth plan, which is to allow the high schools complete freedom, the state departments and the higher schools assuming an attitude of helpful advice and coeperation toward these schools rather than an attitude of direction and prescription, is the one we would advocate.

Many of our educators in colleges and in high schools fear that such a policy would result in chaos in the work of the high schools. How much such a fear is founded on fact and how much on prejudice will have to be determined in each case. But we believe that there are some facts which indicate that this fear is ill founded.

In the first place a very large percentage of the principals and teachers in our secondary schools are college graduates whose prejudices are, for the most part, naturally in favor of the college standards, both in method and material of instruction.

As very convincing evidence of this fact we may again call attention to the replies from high school principals previously cited to the question, "What changes, if any, would you make in your course of study if colleges accepted your graduates, who presented the required number of units, without specifying the subjects in which these units are to be earned?" In this study it appears that $40 \%$ of these principals would make no changes in their courses, and that $60 \%$ would make changes, none of which can be construed as revolutionary or tending in the direction of chaos. 
In the second place those institutions, whose entrance requirements have been most liberal, do not seem to find that students come to them with unwisely selected high school courses. It is true that some students come who do not have the usual college preparatory work, and it is also true that these frequently do well in their college work.

If the high school is to be free from the college, does this mean that they are to be absolutely divorced from each other, the one having nothing to do with the other? Far from it. Instead we would advocate a closer, a far closer, relationship than now exists. Not that relationship of servant and master which can never be close in the true coöperative sense, but the association of equals in the public service is the kind of association we believe is coming. Professor Kirkpatrick in his recent book, "Fundamentals of Sociology," has put the matter most clearly:

"The. . . supposition that the Central authorities can direct the affairs of each community better than the people of the community, is true only in an undemocratic country and where the people of the local communities are ignorant. In a monarchy such centralized control would be consistent, but in a republic, where each local community not only governs itself but takes a part in national and state government, it is quite inconsistent to suppose that they cannot manage their educational affairs.

"This does not mean that the local community should be left entirely without help in solving its educational problems. On the contrary the central educational officials should furnish it with all possible information as to what may be done and as to the most successful means used in other communities. The central officials in education should be to the local school officials what the departments and schools of agriculture are to the farmers of the state. These institutions have no authority whatever over the farmer, but they furnish him reliable information as to what crops may be successfully growh in each kind of soil and how the planting and culture of a crop may be carried on most profitably. In a democracy the state educational officials should aid the local communities. This policy will be far more effective than requiring all to come up to some fixed standard."

President Sanford of Clark College expresses much the same view when he says:

"If there is to be any withdrawal on the part of the college it is only in the sense of getting out of the way and allowing the preparatory school to solve its own problems without unnecessary interference, with friendly, even anxious interest, if you like, with cooperation and advice-as mate with mate-but without undue insistance upon the college point of view; and especially without attempted dictation of any sort." 10

To bring about this kind of helpful relationship between higher schools and secondary schools, or between state de-

- Kirkpatrick, Fundamentals of Sociology, p. 30-3I.

10 Education, I913, Vol. 33, p. 28r. 


\section{RELATION OF SECONDARY TO HIGHER SCHOOLS}

partments and secondary schools we believe two pet schemes of administration and so-called supervision of high schools must be done away with.

The first of these is that the high school inspector, as such, must go, and in his place must come the high school visitor whose function will be entirely advisory and who will have an equal interest in all the courses being offered by the high school, and the same interest in the boy or girl who must leave school at the close of the high school course, that he now has in those who are to continue their studies in college.

The second of these is that the accredited list, on its present basis, must go and in its place must come a standardization from within on a very much broader basis. Such has already been indicated, in part, by some of the requirements of the North Central Association and the Southern Association. But in a democracy these standards and many others, such as the ratio of high school attendance to the number in the community of high school age, the success of former pupils not only in college but in life, the number of strong, healthy, happy children graduated from or attending the high school, must be made the concern of the people who support the school. We believe such standardization can be best and most permanently brought about through education from within rather than from pressure without, such as is now being used, through the system of inspection and accreditation, to bring about a standardization much of which, we fear, tends to retard rather than advance true educational progress in the field of secondary education. 